\title{
Substrate moisture and temperature in Cajanus cajan (L.) Millspaugh germination
}

\section{Umidade do substrato e temperaturas na germinação de Cajanus cajan (L.) Millspaugh}

\author{
Edlânia Maria de Souza ${ }^{1 *}$; Edna Ursulino Alves²; Maria Lúcia Maurício da Silva ${ }^{1}$; \\ Luciana Rodrigues de Araújo ${ }^{3}$; Maria das Mercês Serafim dos Santos Neta ${ }^{1}$
}

\begin{abstract}
Cajanus cajan (L.) Millspaugh, a member of the Fabaceae, is commonly known as feijão-guandu. It was introduced into Brazil because it readily adapts to local climate conditions and tolerates a wide range of water and mineral nutrient levels. The objective of this study was to determine the substrate temperatures and water volumes that are conducive to feijão-guandu seed germination and seedling vigor. The experiment was conducted at the Laboratory of Seed Analysis of the Centre of Agricultural Sciences, Federal University of Paraíba, Areia, PB, Brazil. Seed germination was tested using paper towel rolls moistened with volumes of water equivalent to $2,2.5,3,3.5$, and 4 times the dry mass of the substrate. Variable temperatures in the range of $20{ }^{\circ} \mathrm{C}$ to $30{ }^{\circ} \mathrm{C}$ and constant temperatures of 25 ${ }^{\circ} \mathrm{C}, 30^{\circ} \mathrm{C}$, and $35^{\circ} \mathrm{C}$ were used. The experimental design was completely randomized. The variables analyzed were water content, percent germination, first germination count, germination rate index, and seedling root and shoot lengths and dry weights. Increasing the volume of water used to moisten the substrate hindered feijão-guandu germination at all temperatures. It was determined that moistening the substrate with water volumes equivalent to 2.8 and 3.5 times the substrate dry weight at $30{ }^{\circ} \mathrm{C}$ and 35 ${ }^{\circ} \mathrm{C}$, respectively, were the ideal conditions for evaluating feijão-guandu seed germination and seedling vigor.
\end{abstract}

Key words: Feijão-guandu. Water volumes. Germination tests.

\section{Resumo}

Cajanus cajan (L.) Millspaugh, popularmente conhecido como feijão-guandu é uma Fabaceae que foi introduzida no Brasil por ser uma cultura de fácil adaptação às condições climáticas do país e pouco exigente em água e nutrientes minerais. Dessa forma o objetivo foi determinar o volume de água para umedecimento do substrato e temperatura adequados para testes de germinação e vigor de sementes de feijão-guandu. O trabalho foi realizado no Laboratório de Análise de Sementes, do Centro de Ciências Agrárias, da Universidade Federal da Paraíba, em Areia - PB. As sementes foram submetidas ao teste de germinação em papel-toalha, organizado na forma de rolos e umedecido com volumes de água equivalentes a 2,$0 ; 2,5 ; 3,0 ; 3,5$ e 4,0 vezes a massa do substrato seco, nas temperaturas de 20-30

\footnotetext{
1 Discentes, Programa de Pós-Graduação em Agronomia, Centro de Ciências Agrárias, Universidade Federal da Paraíba, UFPB, Campus, Areia, PB, Brasil. E-mail: edlania.maria@hotmail.com; luciagronomia@hotmail.com; mercesufpb@gmail.com

$2 \operatorname{Prof}^{\mathrm{a}} \mathrm{Dr}^{\mathrm{a}}$, Associada do Departamento de Fitotecnia e Ciências Ambientais, Centro de Ciências Agrárias, UFPB, Campus II, Areia, PB, Brasil. E-mail: ursulinoalves@hotmail.com

$3 \mathrm{Dr}^{\mathrm{a}}$ em Agronomia, Programa de Pós-Graduação em Agronomia, Centro de Ciências Agrárias, UFPB, Campus II, Areia, PB, Brasil. E-mail: 1raraujo1@yahoo.com.br

* Author for correspondence
} 
${ }^{\circ} \mathrm{C}$ alternada e 25,30 e $35{ }^{\circ} \mathrm{C}$ constantes, em delineamento experimental inteiramente ao acaso. As variáveis analisadas foram: teor de água, porcentagem, primeira contagem e índice de velocidade de germinação de sementes, além do comprimento e massa seca de raízes e parte aérea de plântulas. $\mathrm{O}$ aumento do volume de água para umedecimento do substrato foi prejudicial à germinação de sementes de feijão-guandu em todas as temperaturas testadas. O umedecimento do substrato com volumes de água equivalentes a 2,8 e 3,5 vezes a massa do substrato seco, nas temperaturas de 30 e 35 ${ }^{\circ} \mathrm{C}$, respectivamente, é a combinação mais adequada para avaliação da germinação e vigor das sementes de feijão-guandu.

Palavras-chave: Feijão-guandu. Volumes de água. Testes de germinação.

\section{Introduction}

Pigeon pea [Cajanus cajan (L.) Millspaugh], a legume, probably originated in India. It is still widely cultivated there (VAN DER MAESEN, 1990) and was transported to Africa where it is grown as well. It was then introduced in Central and South America (WUTKE, 1987). Pigeon pea is raised mainly in the back yards of many cities in northeastern Brazil. The green (unripe) seeds are sold in open markets and used in animal feed (AZEVEDO et al., 2007).

Pigeon pea is cultivated for phytoremediation. It improves soil conditions, rehabilitates degraded areas, renews pasture, and is used as fodder and food. Feijão-guandu is a good choice for familybased agriculture in the semi-arid regions of Brazil since it adapts well to the climate conditions there (AZEVEDO et al., 2007). According to the same authors, this crop has a high protein content (similar to that of the common bean, Phaseolus vulgaris L.) and significant levels of calcium, iron, magnesium, and phosphorus.

It is essential to know the ideal germination conditions for each crop. Substrate water volume and temperature can significantly influence seed germination. Water surpluses or deficits may adversely affect seed germination (BRASIL, 2009; CARVALHO; NAKAGAWA, 2012).

The minimum amount of water required for germination varies with plant species. As a rule, it is higher for seeds whose storage tissue forms part of the embryo. These include cotton (Gossypium hirsutum L.), peanut (Arachis hypogaea L.), soybean
(Glycine $\max$ L.), and common bean (Phaseolus vulgaris) (POPINIGIS, 1985). Temperature directly influences the rate of water uptake by seeds which, in turn, determines the germination speed and percentage. According to Andrade et al. (2006), substrate temperature affects both the water absorption and metabolism involved in this process. Araújo et al. (2014) found that a water volume equivalent to twice the substrate dry weight and a temperature of $30{ }^{\circ} \mathrm{C}$ were the most conducive to germinating sponge cucumber (Luffa operculata (L.) Cong.) seeds.

Using the temperature best suited for each crop will help to ensure the highest germination percentages in the shortest time (CARVALHO; NAKAGAWA, 2012). The optimum seed germination temperatures for most subtropical and tropical species range between $15{ }^{\circ} \mathrm{C}$ and 30 ${ }^{\circ} \mathrm{C}$. The upper limit lies between $35{ }^{\circ} \mathrm{C}$ and 40 ${ }^{\circ} \mathrm{C}$, at which point the germination rate is very low or even zero (MARCOS FILHO, 2005). For Amburana cearensis (Allemão) A.C. Smith, Guedes et al. (2010) determined that $30^{\circ} \mathrm{C}$ favored higher germination rates whereas $35^{\circ} \mathrm{C}$ inhibited sprouting and reduced seedling vigor. AMARO et al. (2014) evaluated the effects of fixed temperatures (25 ${ }^{\circ} \mathrm{C}$ or $30{ }^{\circ} \mathrm{C}$ ) and variable temperatures (ranging between $20^{\circ} \mathrm{C}$ and $30^{\circ} \mathrm{C}$ ) on melon (Cucumis melo var. capitata L.) seed germination and seedling vigor. They recommended a constant $30{ }^{\circ} \mathrm{C}$ as the most appropriate germination temperature for this species.

The objective of this study was to find the 
substrate water volume and temperature best suited for pigeon pea germination and seedling vigor.

\section{Materials and Methods}

The study was conducted at the Laboratory of Seed Analysis (LAS) of the Center of Agrarian Sciences (CCA), Federal University of Paraíba (UFPB), Areia, PB, Brazil. Pigeon pea seeds were obtained in November 2015 from dried pods harvested at Sítio Bom Jesus, Alagoa Nova, PB and manually threshed at the LAS.

The treatments consisted of four replications of fifty seeds. For each treatment, three paper towel sheets were moistened with distilled water using volumes $\left(\mathrm{mL} \mathrm{g}^{-1}\right)$ equivalent to $2,2.5,3,3.5$, or 4 times the dry weight of the paper. Each lot of fifty seeds was spread on two sheets and covered with a third. The sheets were rolled up, placed in polyethylene bags, and sealed with rubber bands to conserve water. The packages were stored in a Biological Oxygen Demand (B.O.D.) germination chamber adjusted to fixed temperatures of $25{ }^{\circ} \mathrm{C}, 30{ }^{\circ} \mathrm{C}$, and $35{ }^{\circ} \mathrm{C}$ and variable temperatures between $20^{\circ} \mathrm{C}$ and $30^{\circ} \mathrm{C}$. The photoperiod was set to $8 \mathrm{~h}$ light $/ 16 \mathrm{~h}$ dark using daylight fluorescent lamps $(4 \times 20 \mathrm{~W})$. The seeds were pretreated with Captan ${ }^{\mathrm{TM}}$ at a rate of $240 \mathrm{~g} \mathrm{~kg}^{-1}$. The following measurements were made to evaluate pigeon pea germination and seedling vigor:

Water content: determined by oven drying the seeds at $105 \pm 3{ }^{\circ} \mathrm{C}$ for $24 \mathrm{~h}$ (BRASIL, 2009) using four replicates of ten seeds each

Germination percentage: evaluations were performed daily for three to seven days after the start of the experiment; seeds that produced primary roots and shoots (normal seedlings) were scored as germinated (BRASIL, 2009) with modifications.

First germination count: determined by counting the number of normal seedlings (root and shoot emerged) on the third day after the beginning of the experiment; results were expressed as a percentage
Germination rate (GR): germinated seeds were counted daily from three to seven days after the start of the test; the germination rate was calculated using the formula proposed by Maguire (1962)

Length and dry mass of roots and shoots of seedlings: at the end of the germination test, the roots and shoots of all normal seedlings were measured with the aid of a centimeter-graduated ruler. Results were expressed in $\mathrm{cm}$ seedling ${ }^{-1}$. The roots and shoots were excised, placed in kraft paper bags, and heated in a forced-air oven at $65{ }^{\circ} \mathrm{C}$ to a constant weight (48 h). Samples were then weighed on an analytical balance with a precision of $0.001 \mathrm{~g}$ and the results were expressed in g seedling $^{-1}$.

The experimental design was completely randomized with four replicates of fifty seeds. Treatments were arranged in a $5 \times 4$ factorial scheme (water volumes $\mathrm{x}$ temperatures). The data were subjected to ANOVA and higher-order $\left(\mathrm{R}^{2}\right)$ polynomial linear- and quadratic regressions. The means were compared with the Scott-Knott test at the 5\% significance level. Statistical analyses were performed using SISVAR (FERREIRA, 2000).

\section{Results and Discussion}

During the experiment, the pigeon peas had a water content of $12.3 \%$. Over the temperature range of $20{ }^{\circ} \mathrm{C}$ to $30{ }^{\circ} \mathrm{C}$, the germination rate decreased linearly with increasing water volume. The higher germination percentage $(68 \%)$ was obtained when the water volume was equivalent to twice the substrate dry weight. The percentage germination was the lowest $(60 \%)$ at a water volume four times that of the substrate dry weight.

At $25{ }^{\circ} \mathrm{C}$ and $30{ }^{\circ} \mathrm{C}$, the highest germination percentages (65\% and $70 \%$, respectively) were obtained when the substrate was moistened with volumes of water equivalent to 2.6 and 2.5 times the substrate dry weight, respectively. At all other water volumes, germination was negatively affected and decreased by $23 \%$ at $25{ }^{\circ} \mathrm{C}$ and $11 \%$ at $30{ }^{\circ} \mathrm{C}$. At 
$35{ }^{\circ} \mathrm{C}$, maximum germination (67\%) was achieved with a water volume equivalent to 2.5 times the substrate dry weight. At the same temperature, the germination rate decreased by $12 \%$ with a water volume four times the substrate dry weight (Figure 1).

Figure 1. Germination of Cajanus cajan seeds at different temperatures and water volumes on the substrate.

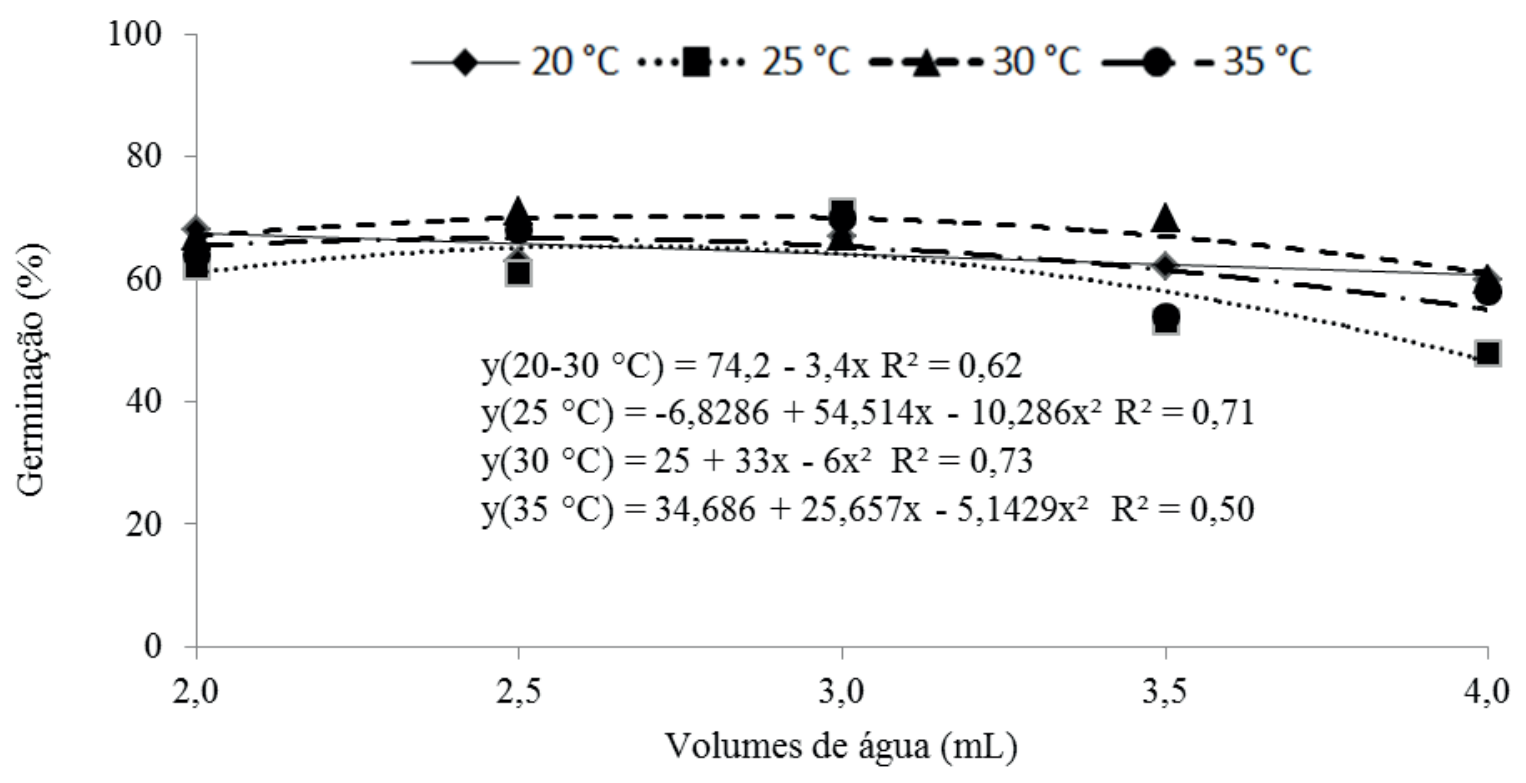

Germinação $(\%)=$ Germination $(\%)$; Volumes de água $(\mathrm{mL})=$ Water volume $(\mathrm{mL})$

At all temperatures (but particularly at $25^{\circ} \mathrm{C}$ ), the application of water at four times the substrate dry weight had adverse effects on seed germination. This observation aligns with that reported by Marcos-Filho et al. (1987), who indicated that a high substrate water volume inhibits seed respiration, delays or arrests germination, and impedes seedling development.

Azeredo et al. (2010) recommended water volumes equivalent to 1.5 to 2.5 times the dry weight of the paper substrate at an alternating temperature of $20{ }^{\circ} \mathrm{C}$ to $30^{\circ} \mathrm{C}$ to germinate cabbage (Brassica oleraceae (L.) H. Lév) seeds. For melon seeds (Cucumis melo), Amaro et al. (2014) verified that $30{ }^{\circ} \mathrm{C}$ resulted in a higher percentage germination. Studies on soybean seeds (Glycine max (L) Merr.) (JACINTO et al., 2014) and sponge cucumber seeds (Luffa operculata) (ARAÚJO et al., 2014) indicated that increasing the amount of water in the substrate significantly reduced the germination percentage.

The first count of pigeon pea seed germination (Figure 2) showed that at alternating temperatures of $20{ }^{\circ} \mathrm{C}$ to $30{ }^{\circ} \mathrm{C}$, seedling vigor declined as the water volume increased. The lowest first count germination percentage $(52 \%)$ occurred when the water volume was equivalent to four times the substrate dry weight. At $25{ }^{\circ} \mathrm{C}$, the highest first count germination percentage $(62 \%)$ was observed when the water volume was equivalent to 2.8 times the substrate dry weight. There was a $26 \%$ reduction in first count germination with a water volume equivalent to four times the substrate dry weight. At $30{ }^{\circ} \mathrm{C}$, maximum germination occurred when the substrate was moistened with a water volume equal to 2.8 times its dry weight. This value was determined mathematically. The lowest percentage 
of germination $(60 \%)$ was obtained with a water volume equivalent to four times the substrate dry weight. At $35{ }^{\circ} \mathrm{C}$, the highest germination percentage $(69 \%)$ occurred with a 2.5 -fold water volume whereas a four-fold water volume reduced the germination percentage to $58 \%$.
In their studies on the Fabaceae species Amburana cearenses and Parkia platycephala Benth., Guedes et al. (2010) and Gonçalves et al. (2015) obtained the highest first count germination percentages when the seeds were subjected to 30 ${ }^{\circ} \mathrm{C}$ and a water volume equal to three times the dry mass of the paper.

Figure 2. First count of Cajanus cajan seed germination at different substrate temperatures and water volumes.

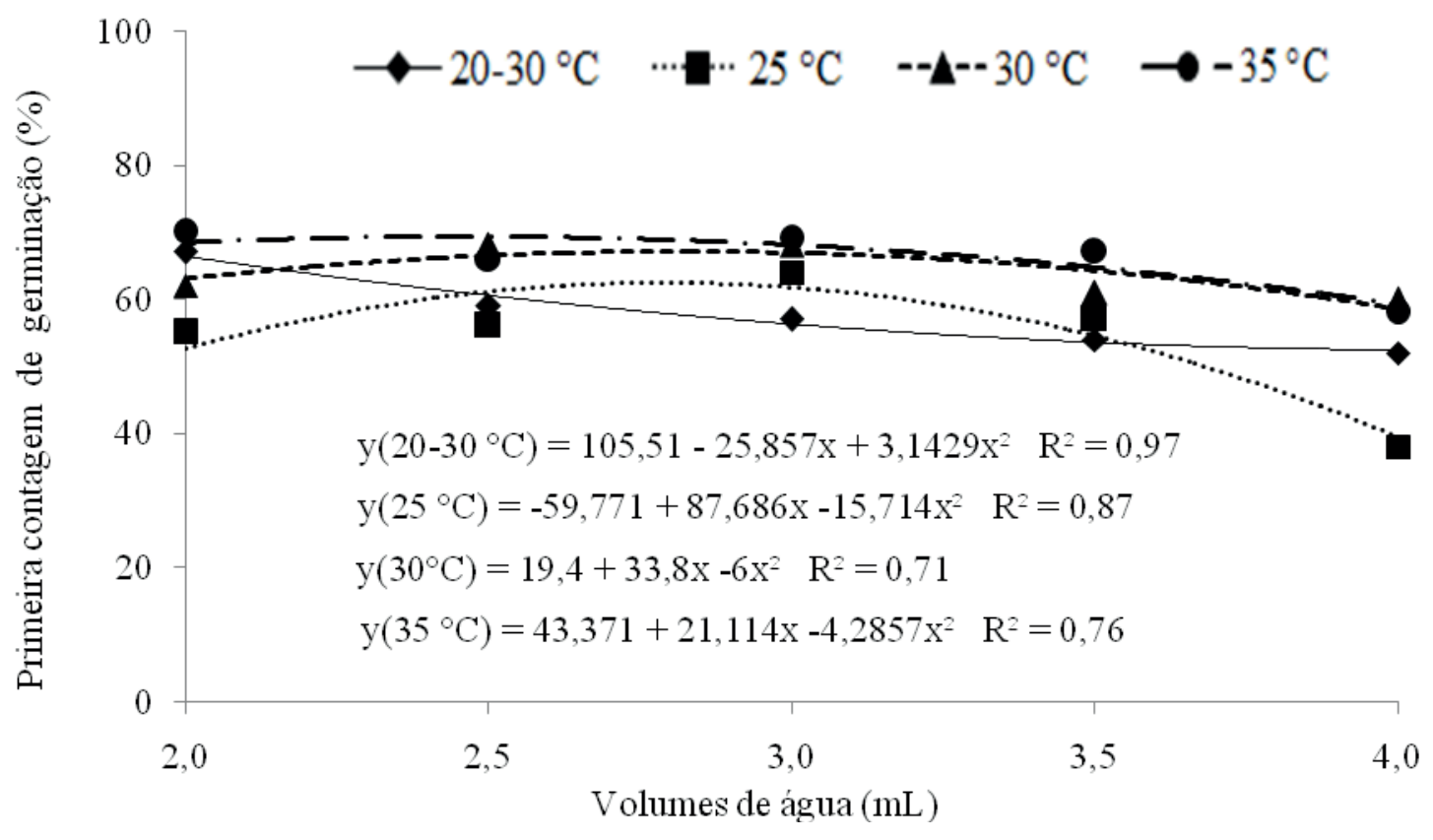

Primeira contagem de germinação (\%) = First germination count $(\%)$;

Volumes de água $(\mathrm{mL})=$ Water volume $(\mathrm{mL})$

The first count germination percentages of sponge cucumber ( $L$. operculata) seeds were the highest at $20^{\circ} \mathrm{C}$ to $30{ }^{\circ} \mathrm{C}$ and at $35^{\circ} \mathrm{C}$ when treated with water volumes equivalent to 2.3 and 3.5 times the dry weight of the paper, respectively (ARAÚJO et al., 2014). The first count germination of whitefleshed pitahaya (Hylocereus undatus Haw.) seeds was the highest at $25^{\circ} \mathrm{C}$ and at $30^{\circ} \mathrm{C}$ using a water volume equivalent to three times the dry mass of the paper (OLIVEIRA JUNIOR et al., 2015).

The lowest germination rate $(10.02 \%)$ was obtained at $20^{\circ} \mathrm{C}$ to $30^{\circ} \mathrm{C}$ using a water volume 3.3 times the dry weight of the paper. At $25^{\circ} \mathrm{C}$, a higher germination rate $(11.02 \%)$ was measured when the substrate was moistened with a water volume equivalent to 2.8 times its dry weight. At $30{ }^{\circ} \mathrm{C}$, the germination rate was $11.66 \%$ when a water volume of 2.9 times the substrate dry weight was added. A germination rate of $12.14 \%$ was obtained at $35{ }^{\circ} \mathrm{C}$ with a water volume of 2.4 times the dry weight of the paper. Nevertheless, when the water volume was increased to four times the substrate dry weight at this temperature, the germination rate declined to $2.83 \%$. As for the germination percentage, 
a water volume of four times the substrate dry weight retarded the germination rate at all fixed temperatures. At alternating temperatures of $20{ }^{\circ} \mathrm{C}$ to $30^{\circ} \mathrm{C}$, however, this inhibitory effect was less severe (Figure 3).

The highest germination rate of melon (Cucumis melo) seeds was observed at a water volume of three times the substrate dry weight at $30^{\circ} \mathrm{C}$ (AMARO et al., 2014). Varela et al. (2005) observed that water volumes 1.5 to 3.0 times the substrate dry weight at $25{ }^{\circ} \mathrm{C}, 30{ }^{\circ} \mathrm{C}$, and $35{ }^{\circ} \mathrm{C}$ did not influence the germination rate of Dinizia excelsa Ducke seeds. Gentil and Torres (2001) found that at $25{ }^{\circ} \mathrm{C}$, the lowest germination rate for West Indian gherkin (Cucumis anguria) seeds was obtained using a water volume equivalent to three times the dry weight of the paper.

Excess water in the substrate can cause rapid imbibition of large volumes of water. This effect can damage cells and reduce germination rates (CSERESNYES; VOROVENCI, 1984). Higher temperatures increase germination rates by accelerating imbibition, biochemical reactions, and physiological processes (CARVALHO; NAKAGAWA, 2012).

Figure 3. Germination rates of Cajanus cajan seeds at different substrate temperatures.

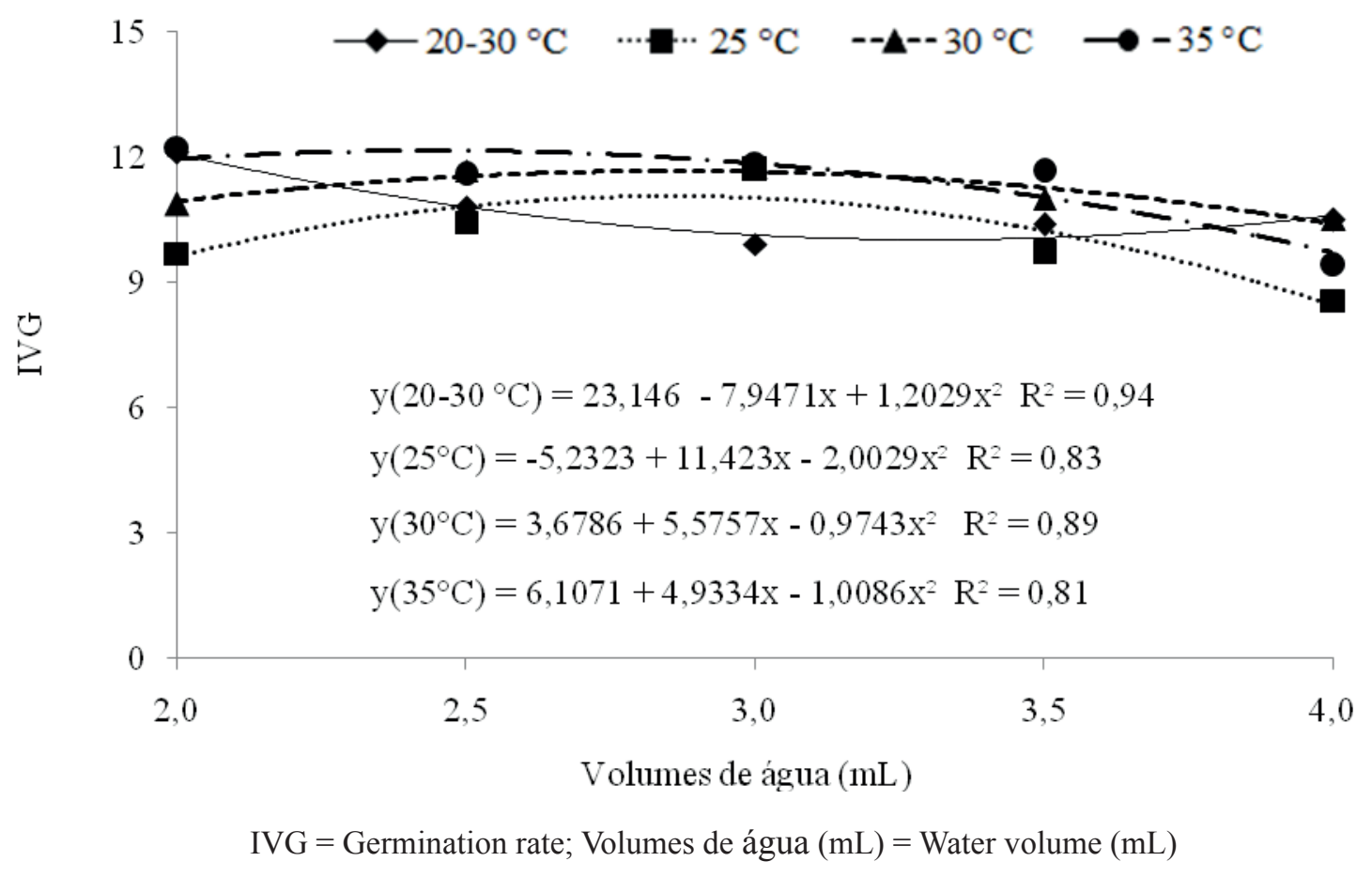

At alternating temperatures of $20{ }^{\circ} \mathrm{C}$ to $30{ }^{\circ} \mathrm{C}$, the longest pigeon pea seedling shoots $(3.41 \mathrm{~cm})$ were obtained with a water volume of 3.5 times the dry substrate weight. At $25^{\circ} \mathrm{C}$, the longest seedling shoots were $2.86 \mathrm{~cm}$ when a water volume of 2.7 times the dry substrate mass was used. At 30
${ }^{\circ} \mathrm{C}$, a volume of water equivalent to 3.3 times the substrate dry weight yielded a maximum seedling shoot length of $3.98 \mathrm{~cm}$. The maximum shoot length was $4.60 \mathrm{~cm}$ with a water volume twice the dry mass of the substrate at $35^{\circ} \mathrm{C}$ (Figure 4). 
Figure 4. Lengths $(\mathrm{cm})$ of Cajanus cajan seedling shoots derived from seeds subjected to different substrate water volumes and temperatures.

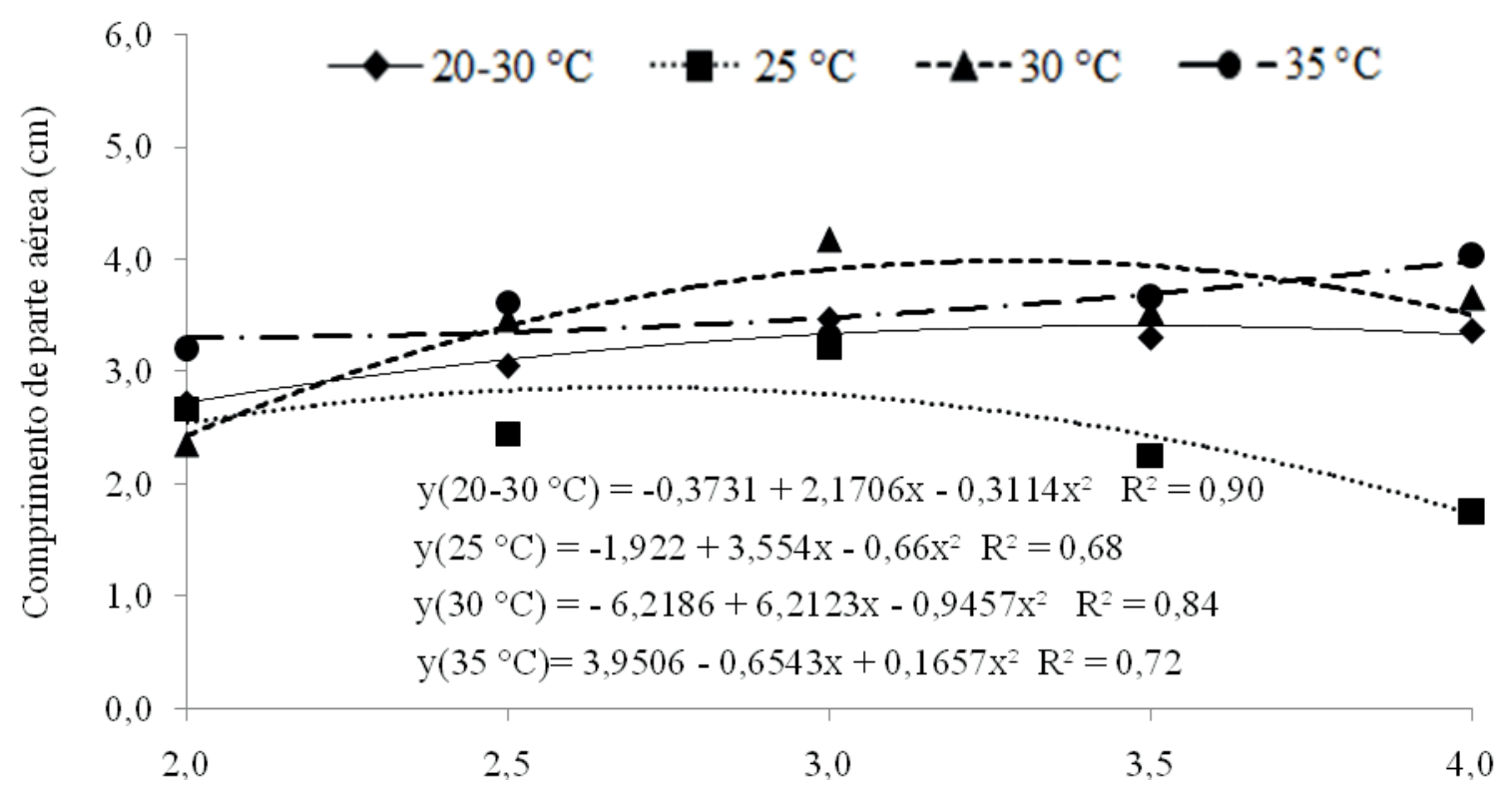

Comprimento de parte aérea $(\mathrm{cm})=$ Length of aerial parts $(\mathrm{cm})$.

MENEZES et al. (1993) studied cucumber (Cucumis sativus L.), melon (Cucumis melo), and watermelon (Citrullus lanatus Thunb.) and observed that the highest substrate water volumes yielded the greatest seedling lengths. Araújo et al. (2014) found that at $35^{\circ} \mathrm{C}$, the shoot length of Luffa operculata seedlings increased with substrate water volume. A temperature of $25^{\circ} \mathrm{C}$ was most inhibitory to balsa tree (Ochroma pyramidale (Cav. exLam.) Urban) shoot growth when water volumes of 1.5, 2, 2.5, and 3 times the dry substrate mass were used (RAMOS et al., 2006).
Pigeon pea seedling root length was greatest $(3.45 \mathrm{~cm})$ when a water volume of 3.0 times the substrate dry weight was used at $20^{\circ} \mathrm{C}$ to $30^{\circ} \mathrm{C}$. At $25^{\circ} \mathrm{C}$, the longest seedling roots $(2.89 \mathrm{~cm})$ occurred with a water volume equivalent to 2.7 times the dry substrate mass. At $30{ }^{\circ} \mathrm{C}$, the greatest root length was $3.43 \mathrm{~cm}$ and was observed with a water volume equivalent to 2.8 times the substrate dry weight. An average root length of $3.55 \mathrm{~cm}$ was determined for seedling roots at $35^{\circ} \mathrm{C}$, but the data did not fit either of the polynomial regressions tested (Figure 5). 
Figure 5. Lengths of Cajanus cajan seedlings roots derived from seeds subjected to different substrate water volumes and temperatures.

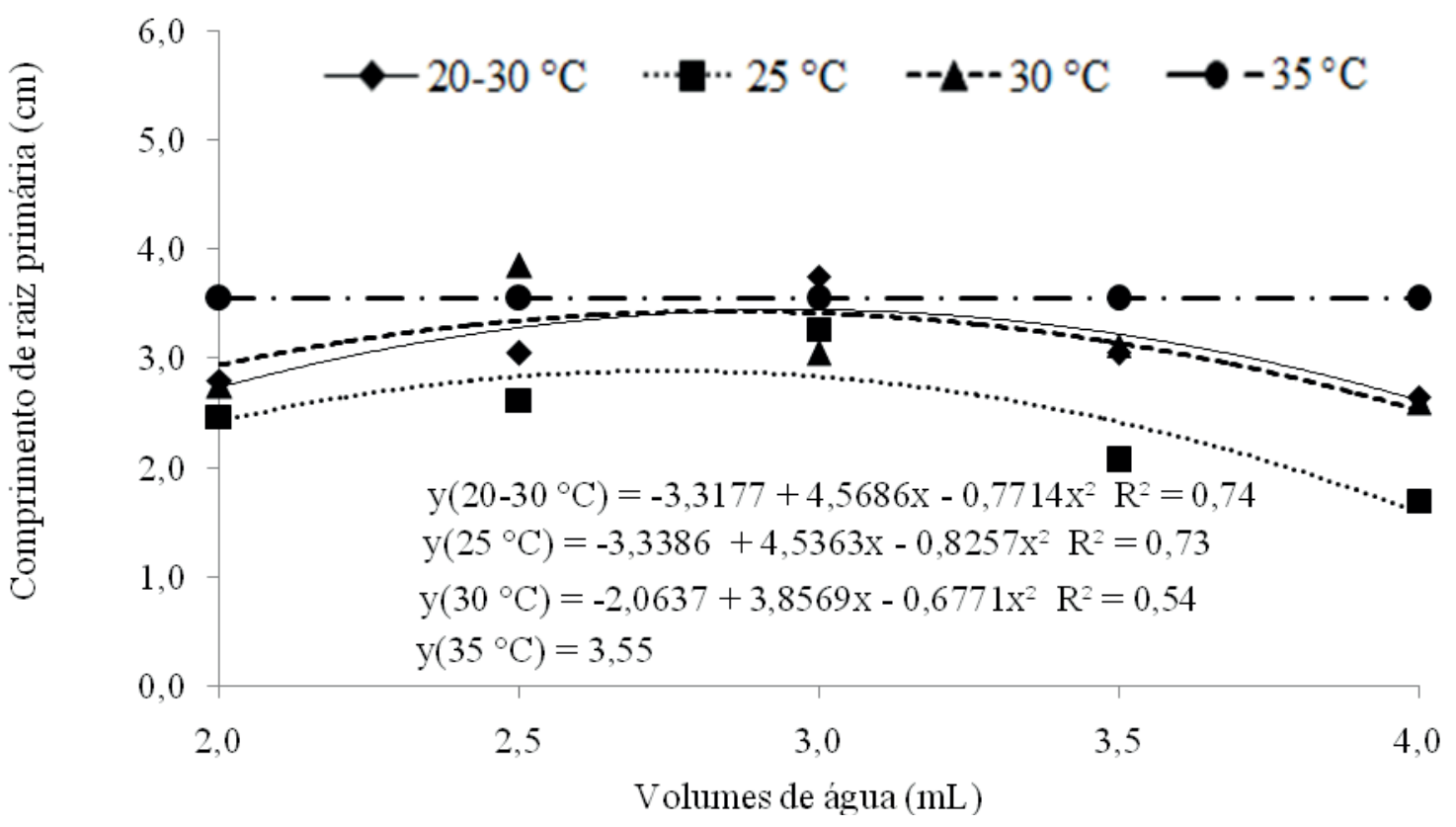

Comprimento da raiz $(\mathrm{cm})=$ Root length $(\mathrm{cm})$; Volumes de água $(\mathrm{mL})=$ Water volume $(\mathrm{mL})$.

Varela et al. (2005) and Ramos et al. (2006) studied gymea lily (Doryanthes excelsa) and balsa tree (Ochroma pyramidale) seeds, respectively. They observed the highest primary root lengths of seedlings at $30{ }^{\circ} \mathrm{C}$ and a water volume equivalent to 1.5 times the substrate dry weight.

The dry weights of pigeon pea seedling shoots (Figure 6) at alternating temperatures of $20{ }^{\circ} \mathrm{C}$ to $30{ }^{\circ} \mathrm{C}$ and at constant temperatures of $25{ }^{\circ} \mathrm{C}$ and $35{ }^{\circ} \mathrm{C}$ did not fit any polynomial regression model. Their means were $0.0080 \mathrm{~g}, 0.0081 \mathrm{~g}$, and $0.0078 \mathrm{~g}$, respectively. At $30{ }^{\circ} \mathrm{C}$, a water volume equivalent to 1.8 times the substrate dry weight resulted in the highest seedling dry weight (0.00008 g).

Although substrate temperature influenced Amburana cearensis seedling dry weight, substrate water volumes $(2,2.5,3$, or 3.5 times that of the substrate dry mass) did not. The highest seedling dry weights were obtained at $30^{\circ} \mathrm{C}$ (GUEDES et al., 2010). For white-fleshed pitahaya seeds (Hylocereus undatus), the highest seedling dry weights were observed at $25{ }^{\circ} \mathrm{C}$ and a water volume equivalent to 3.5 times the substrate dry weight (OLIVEIRA JUNIOR et al., 2015).

Data for the pigeon pea seedling root dry weights did not fit any polynomial regression. The means at alternating temperatures of $20{ }^{\circ} \mathrm{C}$ to $30^{\circ} \mathrm{C}$ and at constant temperatures of $25^{\circ} \mathrm{C}$ and $35^{\circ} \mathrm{C}$ were $0.0090 \mathrm{~g}, 0.0068 \mathrm{~g}$, and $0.0071 \mathrm{~g}$, respectively. At $30{ }^{\circ} \mathrm{C}$, the root dry mass significantly decreased with increasing substrate water volume (Figure 7). 
Figure 6. Dry weights of Cajanus cajan shoots derived from seeds treated with different substrate water volumes and temperatures.

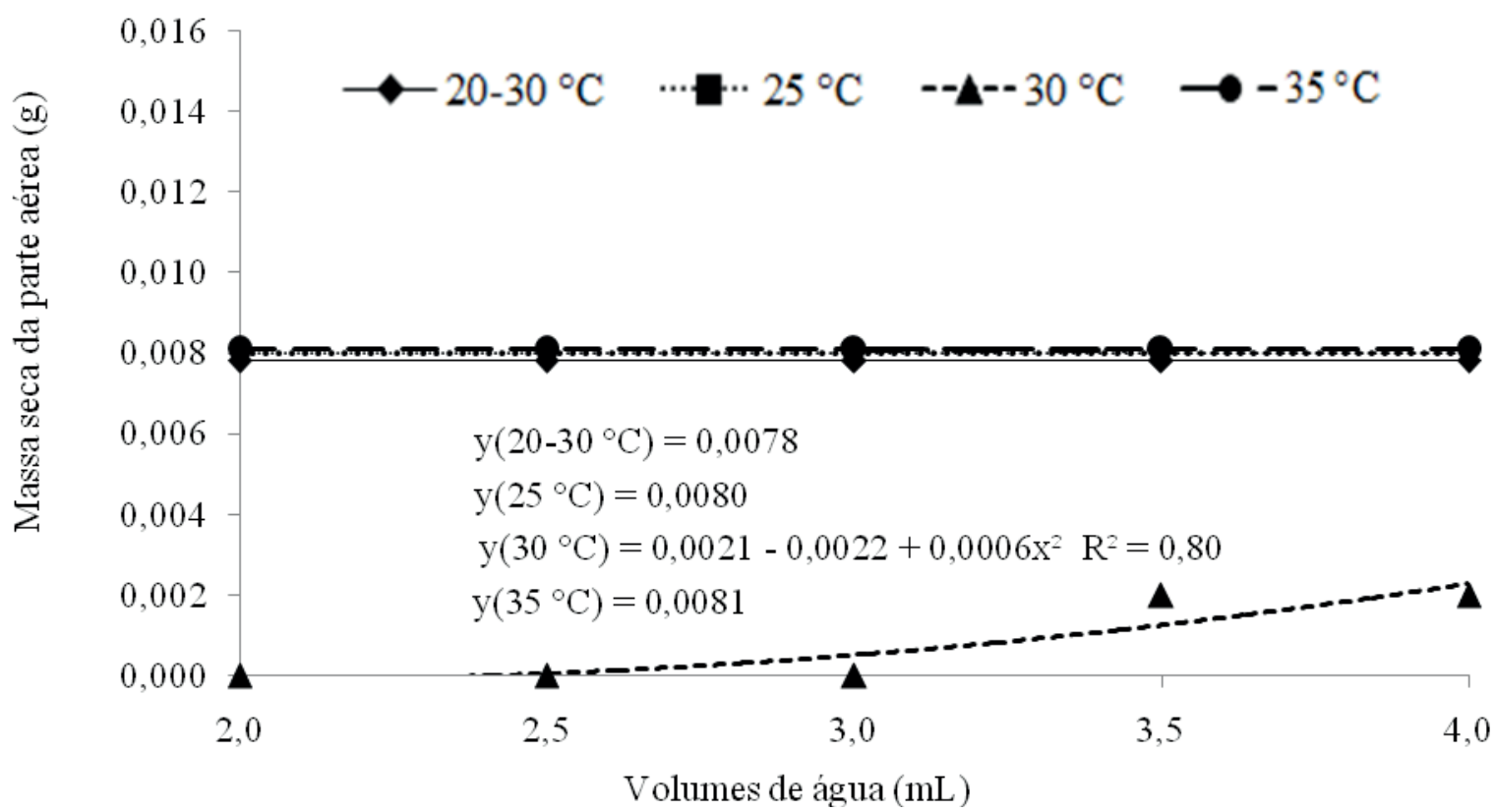

Massa seca da parte aérea $(\mathrm{g})=$ Aerial dry mass $(\mathrm{g})$; Volumes de água $(\mathrm{mL})=$ Water volume $(\mathrm{mL})$.

Figure 7. Dry weights of Cajanus cajan roots derived from seeds treated with different substrate water volumes and temperatures.

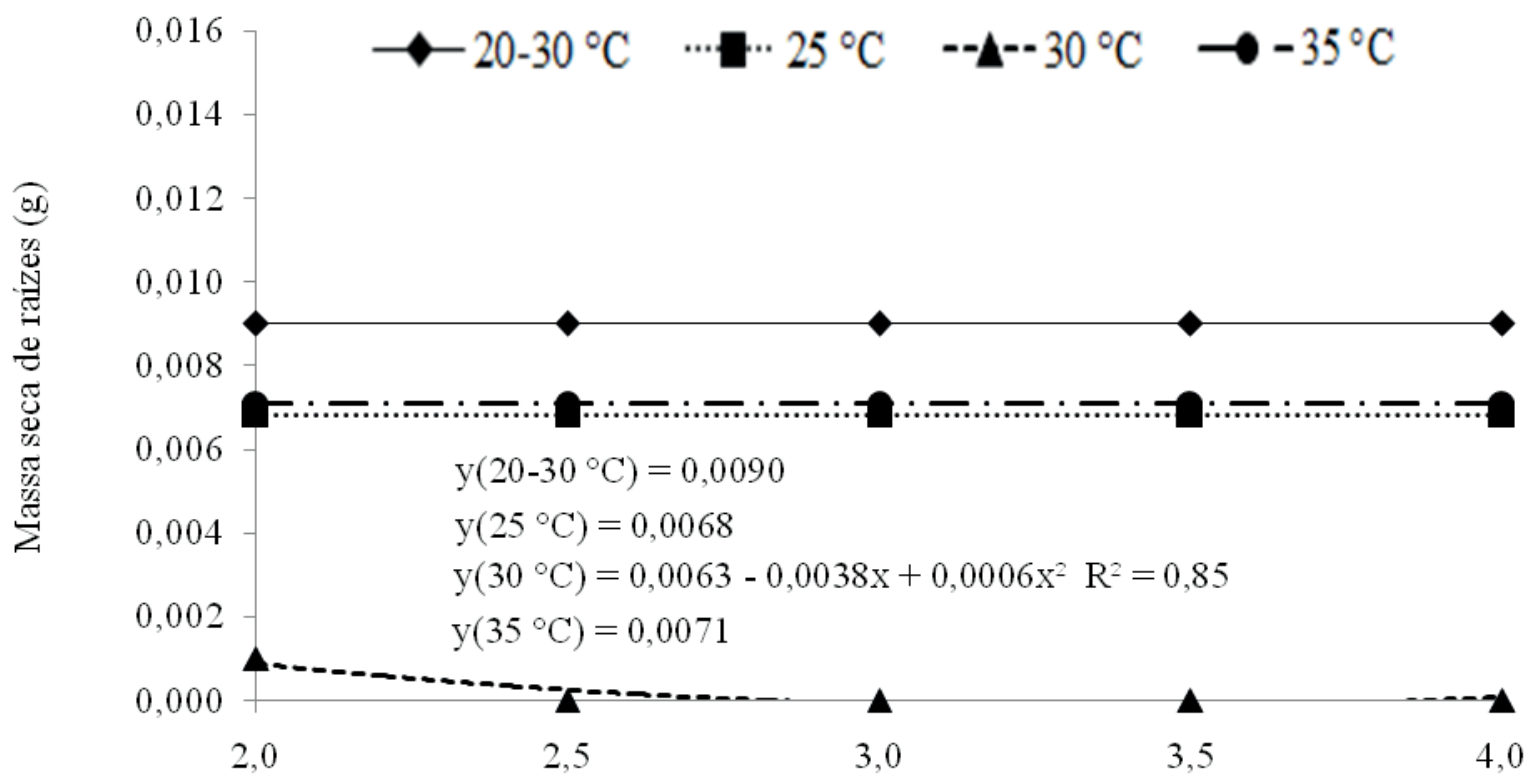

Volumes de água (mL)

Massa seca de raízes $(\mathrm{g})=$ Dry weight of roots $(\mathrm{g})$; Volumes de água $(\mathrm{mL})=$ Water volumes $(\mathrm{mL})$. 
Parkia platycephala seedling root dry weights were not affected by substrate water volumes. Nevertheless, substrate temperatures of $25^{\circ} \mathrm{C}$ and $30{ }^{\circ} \mathrm{C}$ resulted in the highest seedling dry mass (GONÇALVES et al., 2015). Amaro et al. (2014) proposed that optimizing the substrate temperature and water volume for seed germination would help minimize variation in laboratory germination tests and increase crop yields for growers.

\section{Conclusions}

Pigeon pea seed germination and seedling vigor evaluation can be optimized by using substrate water volumes equivalent to 2.8 and 3.5 times the substrate dry mass and substrate temperatures of 30 ${ }^{\circ} \mathrm{C}$ and $35^{\circ} \mathrm{C}$, respectively.

\section{References}

AMARO, H. T. R.; DAVID, A. M. S. S.; CANGUSSÚ, L. V. S.; RODRIGUES, B. R. A.; ASSIS, M. O.; VELOSO, C. S. Umedecimento do substrato e temperatura na germinação e vigor de sementes de melão. Semina: Ciências Agrárias, Londrina, v. 35, n. 3, p. 1119-1130, 2014.

ANDRADE, A. C. S.; PEREIRA, T. S.; FERNANDES, M. J.; CRUZ, A. P. M.; CARVALHO, A. S. R. Substrato, temperatura de germinação e desenvolvimento pósseminal de sementes de Dalbergia nigra. Pesquisa Agropecuária Brasileira, Brasília, v. 41, n. 3, p. 517-523, 2006.

ARAÚJO, P. C.; ALVES, E. U.; URSULINO, M. M.; ARAÚJO, L. R.; SILVA, R. S. Different water volumes in the substrate and temperatures for germination of cabacinha seeds. Horticultura Brasileira, Brasília, v. 32, n. 3, p. 367-370, 2014.

AZEREDO, G.A.; SILVA, B. M. S.; SADER, R.; MATOS, V. P. Umedecimento e substratos para germinação de sementes de repolho. Pesquisa Agropecuária Tropical, Goiânia, v. 40, n. 1, p. 77-82, 2010.

AZEVEDO, R. L.; RIBEIRO, G. T.; AZEVEDO, C. L. L. Feijão guandu: uma planta multiuso. Revista da Fapese, Aracajú, v. 3, n. 2, p. 81-86, 2007.

BRASIL. Ministério da Agricultura, Pecuária e Abastecimento. Regras para análise de sementes.
Secretaria de Defesa Agropecuária. Brasília: MAPA/ ACS, 2009. 395 p.

CARVALHO, N. M.; NAKAGAWA, J. Sementes: ciência, tecnologia e produção. 5. ed. Jaboticabal: FUNEP, 2012. $590 \mathrm{p}$.

CSERESNYES, Z.; VOROVENCI, O. Improved method for Glycine max seed germination by improving seed water supply. Seed Science and Technology, Zürich, v. 12, n. 2, p. 679-685, 1984.

FERREIRA, D. F. SISVAR. Sistema para análise de variância. Lavras: UFL/DEX, 2000. CD-ROM.

GENTIL, D. F. O.; TORRES, S. B. Umedecimento do substrato e germinação de sementes de maxixe (Cucumis anguria L.). Revista Brasileira de Sementes, Londrina, v. 23, n. 2, p. 113-116, 2001.

GONÇALVES, E. P.; FRANÇA, P. R. C.; VIANA, J. S.; ALVES, E. U.; GUEDES, R. S.; LIMA, C. R. Umedecimento do substrato e temperatura na germinação de sementes de Parkia platycephala Benth. Ciência Florestal, Santa Maria, v. 25, n. 3, p. 563-569, 2015.

GUEDES, R. S.; ALVES, E. U.; GONÇALVES, E. P.; VIANA, S. J.; FRANÇAS, P. R. C.; LIMA, C. R. Umedecimento do substrato e temperatura na germinação e vigor de sementes Amburana cearensis (All.) A. C. Smith. Revista Brasileira de Sementes, Lavras, v. 32, n. 3, p. 116-122, 2010.

JACINTO, J. T. D.; BENETT, K. S. S.; BENETT, C. G. S. Influência do substrato e do teor de água sobre a germinação de sementes de soja. Agricultura Neotropical, Cassilândia, v. 1, n. 1, p. 97-102, 2014.

MAGUIRE, J. D. Speed of germination-aid in selection and evaluation of seedling emergence and vigor. Crop Science, Madson, v. 2, n. 2, p. 176-177, 1962.

MARCOS FILHO, J. Fisiologia de sementes de plantas cultivadas. Piracicaba: FEALQ, 2005. 495 p.

MARCOS-FILHO, J.; CICERO, S. M.; SILVA, W. R. Avaliação da qualidade das sementes. Piracicaba: FEALQ, 1987. $230 \mathrm{p}$.

MENEZES, N. L.; SILVEIRA, T. L. D.; STORCK, L. Efeito do nível de umedecimento do substrato sobre a germinação de cucurbitáceas. Ciência Rural, Santa Maria, v. 23, n. 2, p. 157-160, 1993.

OLIVEIRA JUNIOR, J. L.; ALMEIDA NETA, M. N.; DAVID, A. M. S. S.; AGUIAR, A. C. M.; GOMES, A. G. O.; AMARO, H. T. R.; DONATO, L. M. S. Umedecimento do substrato e temperatura na germinação e vigor de sementes de pitaya. Comunicata Scientiae, Bom Jesus, v. 6, n. 3, p. 282-290, 2015. 
POPINIGIS, F. Fisiologia da semente. Brasília: the Semi-Arid Tropics, 1990. p. 15-46. AGIPLAN, 1985. 289 p.

VARELA, V. P.; RAMOS, M. B. P.; MELO, M. F. F. RAMOS, M. B. P.; VARELA, V. P.; MELO, M. F. F. Influência da temperatura e da quantidade de água no substrato sobre a germinação de sementes de Ochroma pyramidale (Cav. exLam.) Urban (pau-de-balsa). Acta Amazonica, Manaus, v. 36, n. 1, p. 103-106, 2006.

VAN Der MAESEN, L. J. G. Pigeonpea: origin, history, evolution and taxonomy. In: NENE, Y. L.; HALL, S. D.; SHEILA, V. K. (Ed.). Pigeonpeas. Oxford: CAB International/ International Crops Research Institute for Umedecimento do substrato e temperatura na germinação de sementes de angelim-pedra (Dinizia excelsa Ducke). Revista Brasileira de Sementes, Pelotas, v. 27, n. 2, p. 130-135, 2005.

WUTKE, E. B. Caracterização fenológica e avaliação agronômica de genótipos de guandu (Cajanus cajan (L.) Millsp.). 1987. Dissertação (Mestrado em Agronomia) - Escola Superior de Agricultura Luiz de Queiroz. Universidade de São Paulo, Piracicaba. 
